\title{
Where do Treating Physicians Belong as Witnesses in The SeVenth Circuit?
}

\author{
Courtney E. Campbell ${ }^{*}$
}

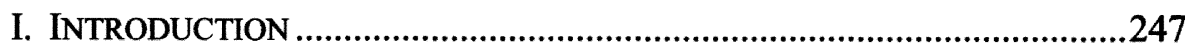

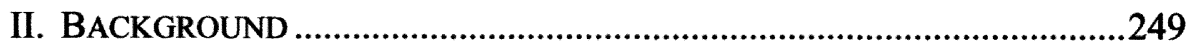

A. Case Law Prior to the 1993 Rule 26 Amendments .................249

B. The 1993 Amendments to Rule 26(a) .....................................250

C. Survey of Cases in United States Federal Courts....................251

1. Failure to Disclose May Not Preclude Treating Physician from Testifying ......................................................................252

2. After Designation as an Expert, Should a Report Be

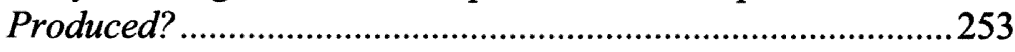

a. Expert report required only when testifying to causation, prognosis, and/or future disability .......................................254

$b$. Depends on the extent of the treating physician's

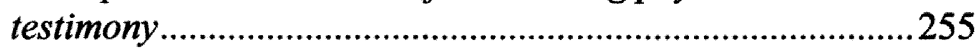

D. Seventh Circuit's Management of Treating Physicians...........261

1. Being Retained Creates a Report Requirement ...................264

2. Causation Creates a Report Requirement............................264

3. Disclosure Depends on How the Information Was

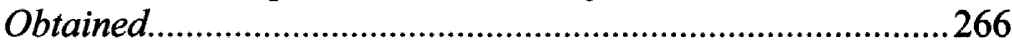

E. Lingering Problems …………………………………......269

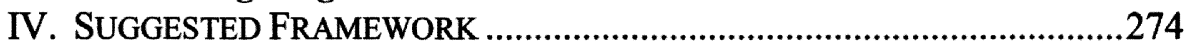

A. Taking into Account the Purposes of Treating Physicians'

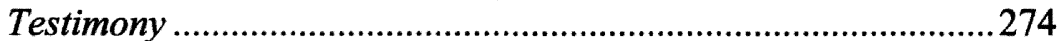

B. Balancing Test Proposition.....................................................276

C. When Treating Physicians Are Designated Experts Needing

to Produce a Summary Report, What Should Be Included?..........277

V. CONCLUSION

\section{INTRODUCTION}

Within the scope of Rule 26 of the Federal Rules of Civil Procedure, it has been difficult to determine a role for the treating physician as a witness. The "[amended federal] rules of discovery and evidence have camouflaged the treating physician. The time has come to explore the forest of precedent

* J.D. Candidate, 2012, Indiana University School of Law—Indianapolis; B.A., 2006, University of Notre Dame. 
in search of that chameleon."1 Whether a physician should be treated as a fact witness or an expert witness in federal courts has been a matter of debate for some time because of their dual roles as both types of witnesses. ${ }^{2}$ As fact witnesses, treating physicians testify as "first-hand participants in the diagnosis and treatment of the plaintiff," yet "diagnosis and treatment are almost certainly informed by the physician's specialized training and knowledge." 3 In other words, treating doctors are first-hand observers of what has occurred to their patients, but may also be seen as scientific experts when speaking to complex medical issues. ${ }^{4}$

Before the 1993 amendments to Federal Rule of Civil Procedure 26(a), a doctor needed to be disclosed as an expert only when he was testifying as to causation or speaking beyond the scope of his or her treatment of a patient. ${ }^{5}$ Whether a witness was an expert depended on the "not status of the witness, but rather on the substance of the testimony." In addition, experts were not required to produce an expert report. ${ }^{7}$

However, the 1993 amendments to Rule 26 and subsequent case law changed this process by requiring those who are retained in anticipation of litigation to provide an expert report. ${ }^{8}$ Rule 26 was amended again in December 2010 to require a summary report from even those witnesses who are not retained in anticipation of litigation."

As a result of these developments, the time is ripe to definitively decide how treating physicians should be categorized in the Seventh Circuit. This note will generally discuss whether a physician should be treated as a

1. Dorothea Beane \& Theodore E. Karatinos, Catching the Chameleon: When Is the Treating Physician an Expert?, FED. LAw., May 2004, at 26.

2. Eric S. Dreiband, Recent Developments in Disabilities Discrimination and Litigation: Use of Expert Witnesses, in EMPLOYMENT DISCRIMINATION LAW AND LITIGATION 2010, 291, 295 (PLI Litig. \& Admin. Practice, Course Handbook Ser. Order No. 23389, 2010).

3. Id.

4. The Federal Rules of Evidence draw a line between expert testimony and fact testimony. FED. R. EVID. 701 qualifies lay witness fact testimony as, "limited to those opinions or inferences which are (a) rationally based on the perception of the witness, (b) helpful to a clear understanding of the witness' testimony or the determination of a fact in issue, and (c) not based on scientific, technical, or other specialized knowledge within the scope of Rule 702." Alternatively, FED. R. EVID. 702 describes testimony by experts as when "scientific, technical, or other specialized knowledge will assist the trier of fact to understand the evidence or to determine a fact in issue," and such a witness is "qualified as an expert by knowledge, skill, experience, training, or education."

5. FED. R. CIV. P. 26 advisory committee's note (1970). See, e.g., Canterbury v. Spence, 464 F.2d 772, 791-92 (D.C. Cir. 1972) ("Experts are ordinarily indispensible to identify and elucidate for the factfinder the risks of therapy and the consequences of leaving existing maladies untreated. They are normally needed on issues as to the cause of any injury or disability suffered by the patient and, where privileges are asserted, as to the existence of any emergency claimed and the nature and seriousness of any impact upon the patient from risk-disclosure.").

6. Patel v. Gayes, 984 F.2d 214, 218 (7th Cir. 1993).

7. Shapardon v. W. Beach Estates, 172 F.R.D. 415,417 (D. Haw. 1997).

8. FED. R. CIV. P. 26(a)(2)(B) (repealed 2010).

9. FED. R. CIV. P. 26(a)(2)(C). 
fact witness or an expert witness. Part II will examine the historical background of this issue, including (a) an examination of the case law prior to 1993, (b) the 1993 Rule 26 amendments, (c) a survey of methods taken in response to the 1993 Rule 26 amendments, (d) a survey of cases in the Seventh Circuit, and (e) a consideration of the problems lingering from these strategies. Part III will discuss the new addition to Rule 26 and its potential ramifications. Part IV will propose a framework for where to place treating physicians within the context of the amended Federal Rule of Civil Procedure 26.

\section{BACKGROUND}

In order to improve this system, it is important to first understand the history behind it. Before the December 2010 Rule 26 amendments, there were two other important amendments that affected treating physicians under Rule $26,{ }^{10}$ occurring first in $1970,{ }^{11}$ and then in $1993 .{ }^{12}$ The expert witness status of treating physicians has drastically changed with each amendment. ${ }^{13}$ Although both amendments set standards for disclosures of experts, each essentially left federal courts to decide on their own how to categorize a plaintiff's treating physician, creating problems that have lingered to present day.

\section{A. Case Law Prior to the 1993 Rule 26 Amendments}

Until 1993, Rule 26 did not affect the expert whose information was not obtained in anticipation of litigation "because he was an actor or viewer with respect to transactions or occurrences that are part of the subject matter of the lawsuit." ${ }^{\prime 14}$ These witnesses were instead treated as ordinary witnesses. ${ }^{15}$ Furthermore, experts did not need to produce reports before the 1993 amendments to Rule 26. ${ }^{16}$ Regardless of whether they were obtained in anticipation of litigation, parties were merely given equal opportunity to interview opposing experts through interrogatories. ${ }^{17}$ In these interrogatories, experts could be asked to "state the subject matter on which the expert

10. See FeD. R. Civ. P. 26 (1970); FED. R. Civ. P. 26 (repealed 1993); FED. R. Crv. P. 26 (repealed 2010).

11. FED. R. Crv. P. 26(b)(4)(A) (repealed 1993).

12. FED. R. Civ. P. 26(b)(4)(A) (repealed 2010).

13. See generally FED. R. CIV. P. 26 (1970); FED. R. CIV. P. 26 (repealed 1993); FED. R. CIV. P. 26 (repealed 2010); FED. R. CIV. P. 26.

14. FED. R. Crv. P. 26 advisory committee's note (1970).

15. Id.

16. See generally FED. R. Crv. P. 26 (repealed 1993). See, e.g., Patel v. Gayes, 984 F.2d 214, 217 (7th Cir. 1993); Schurr v. Niagara Mach. \& Tool Works, No. Civ. A. No. 895422, 1991 WL 3875, at *1-2 (E.D. Penn. Jan. 9, 1991).

17. 8A Charles alan Wright et al., Federal Practice \& Procedure $§ 2031.2$ (3d ed. 2010). 
is expected to testify, and to state the substance of the facts and opinions to which the expert is expected to testify and a summary of the grounds for each opinion." 18

Before 1993, the Seventh Circuit determined whether a treating physician needed to be disclosed as an expert before trial under Rule 26 by "focus[ing] not on the status of the witness, but rather on the substance of the testimony."19 Accordingly, a doctor who was "acquired or developed in anticipation of litigation or for trial" would be more likely considered an expert. ${ }^{20}$ Doctors gave "“classic' expert testimony" by opining as to "the general medical standard of care within the community," since "[a] witness would formulate such an opinion only when preparing for litigation.",21

\section{B. The 1993 Amendments to Rule 26(a)}

The 1993 Rule 26(a) amendments were considered by some to be controversial and the "most sweeping changes since the rules first were adopted in 1938."22 Newly amended Rule 26(a)(2)(B) provided,

Unless otherwise stipulated or ordered by the court, this [expert] disclosure must be accompanied by a written report - prepared and signed by the witnessif the witness is one retained or specially employed to provide expert testimony in the case or one whose duties as the party's employee regularly involve giving expert testimony. ${ }^{23}$

These changes were quite a departure from the past requirements, as they greatly enhanced the disclosure requirements for retained experts by requiring an "extremely detailed report" as opposed to "the rather general

18. Id. (quoting FED. R. CIV. P. 26(b)(4)(A) (1970) (repealed 1993)). See also Nelco Corp. v. Slater Elec. Inc., 80 F.R.D. 411, 414 (E.D.N.Y. 1978) ("[U]nder Rule 26(b)(4)(A), a witness sought to be discovered may be an 'expert' as to some matters and an 'actor' as to others."); Patel, 984 F.2d at 218 ("Under the Federal Rules, an expert must be identified if his testimony does not come from his personal knowledge of the case, or if his knowledge was acquired or developed in anticipation of litigation or for trial.") (citations omitted); accord Quarantillo v. Consol. Rail Corp., 106 F.R.D. 435, 437 (W.D.N.Y. 1985).

19. Patel, 984 F.2d at 218. See also Jenkins v. Whittaker Corp., 785 F.2d 720, 728 (9th Cir. 1986), cert. denied, 479 U.S. 918 (1986); Grinnell Corp. v. Hackett, 70 F.R.D. 326, 331 (D.R.I. 1976); Quarantillo, 106 F.R.D. at 437 ("Rule 26(b)(4) sets forth restrictions upon discovery of facts known and opinions held by experts that had been acquired or had been developed in anticipation of litigation or for trial.").

20. Patel, 984 F.2d at 218 (quoting Grinnell Corp., 70 F.R.D. at 331).

21. Id.

22. Joseph E. Stevens, et al., Practical Aspects of the Revisions to the Federal Rules of Civil Procedure Effective 12/1/93, 50 J. Mo. B. 341, 341 (quoting Randall Samborn, Bill to Stop Changes: New Discovery Rules Take Effect, NaT'L L. J., Dec. 6, 1993, at 3).

23. FED. R. Crv. P. 26(a)(2)(B) (repealed 2010). 
interrogatory authorized by the 1970 provisions." 24 These amendments were generated because under the former rule, "answering interrogatories about the 'substance' of expert testimony was frequently so sketchy and vague that it rarely dispensed with the need to depose the expert and often was even of little help in preparing for a deposition of the witness." ${ }^{25}$ In tandem with the revised Rule 37(c)(1), the Rule 26 amendments also created incentives for full disclosure, as "a party [would] not ordinarily be permitted to use on direct examination any expert testimony not so disclosed." 26 The formal report requirement included the need for his or her opinions, bases for his or her opinions, and all material "considered" by the expert. $^{27}$

This report preparation requirement was particularly significant because before the change, experts were rarely asked to prepare an early report, and when they did prepare such a report, it often "lock[ed] the expert into opinions and subject[ed] her to limiting cross-examination." 28 Yet, the new requirements simultaneously left enormous ambiguity as to when a treating physician was a fact witness and as to when an expert needed to produce a report.

\section{Survey of Cases in United States Federal Courts}

Without much formal guidance as to those witnesses who were not retained in anticipation of litigation, federal courts had difficulty navigating the 1993 changes to Rule $26^{29}$ Moreover, because the Supreme Court has not considered the role of treating physicians under Rule 26 , courts were left to determine what to do with treating physicians. As a result, courts have interpreted Rule 26 in various ways. ${ }^{30}$ An advisory committee note

24. 8A WRIGHT ET AL., supra note 17.

25. FED. R. CIV. P. 26 (repealed 1993). See also Meyers v. Nat'l R.R. Passenger Corp. (Amtrak), 619 F.3d 729, 734 (7th Cir. 2010) ("The purpose of the report is to provide adequate notice of the substance of the expert's forthcoming testimony and to give the opposing party time to prepare for a response.").

26. FED. R. CIv. P. 26 advisory committee's note (1993). See also Meyers v. Nat'l R.R. Passenger Corp. (Amtrak), 619 F.3d 729, 734 (7th Cir. 2010) (finding that the consequences of not producing a report are also particularly important because failure to do so may result in the exclusion of the expert's testimony pursuant to Rule 37(c)(1)).

27. FED. R. CIV. P. 26(a)(2)(B) (repealed 2010); Eric K. Yamamoto \& Joseph L. Dwight, IV, Procedural Politics and Federal Rule 26: Opting-Out of "Mandatory" Disclosure, 16 U. HAw. L. REV. 167, 181 (1994).

28. Yamamoto \& Dwight, supra note 27.

29. Lee H. Rosenthal, New Areas of Review by the Advisory Committee on Civil Rules, Including Rules 13, 15, 26(A)(2)(B), 48, and 62.1, and Broader Civil Procedure Projects, Including Time Computation, Summary Judgment, and Notice Pleading, in CIVIL Practice and Litigation Techniques in Federal and State Courts (ALI-ABA Course of Study, 2007).

30. See Gregory P. Joseph, Emerging Issues Under the 1993 Amendments to the Federal Civil Rules, in CURRENT DeVElopments IN Federal Civil Practice 1999 335, 370-71 
left some clues, however, stating that a treating physician "can be deposed or called to testify at trial without any requirement for a written report."

Most federal courts do require the disclosure of a treating physician as an expert by a patient. ${ }^{32}$ However, failure to disclose does not necessarily lead to the exclusion of that doctor. ${ }^{33}$ Moreover, no clear consensus has been reached amongst federal courts on the expert report requirement, resulting in the use of several approaches. ${ }^{34}$

\section{Failure to Disclose May Not Preclude Treating Physician from} Testifying

For some courts, failure to disclose a treating physician as an expert witness does not necessarily prevent a party from utilizing the physician's factual testimony at trial. ${ }^{35}$ Courts following a more narrow approach conclude that those treating physicians whom parties fail to designate as an expert witness "generally may only testify as to the observations they made regarding the plaintiff during the course of treatment." ${ }^{\text {,6 }}$ For example, in Aumand v. Dartmouth Hitchcock Medical Center, the court found that the disclosure of a treating physician was required under Rule $26(\mathrm{a})(2)(\mathrm{A})$ because "a treating physician's diagnoses, prognoses, or other conclusions as to the patient's condition ... . are examples of the physician's 'specialized knowledge," which are indicative of expert testimony under Federal Rule of Evidence $702 .^{37}$ However, those treating physicians who were not disclosed under Rule 26(a)(2)(A) could still testify as fact witnesses regarding "what they saw and what they did in the course of caring for a patient."38

In addition, the court in Kirkpatrick v. Pfizer, Inc. allowed the plaintiff's treating physician to testify as to causation even though the plaintiff had failed to disclose the physician as an expert under Rule $26(\mathrm{a})(2)(\mathrm{A}){ }^{39}$

(PLI Litig. \& Admin. Practice, Course Handbook Ser. No. H0-002M, 1999).

31. FED. R. CIv. P. 26 advisory committee's note (1993).

32. JOHN KIMPFLEN ET AL., 10 FEDERAL PROCEDURE LAWYERS EDITION $§ 26: 50$ (2010). See also Lori G. Cohen \& Christiana C. Jacxsens, When Is an Expert Not an Expert? Rule 26 Disclosures of Treating Physicians, LJN's Prod. LIAB. L. \& STRATEGY, July 2010 ("Across jurisdictions, most courts have found that a treating physician may have expert opinions and should thus be disclosed as an expert witness under Rule 26(a)(2)(A)."). See, e.g., Redfoot v. B.F. Ascher \& Co., No. C 05-2045 PJH, 2007 WL 1593239, at *13 (N.D. Cal. June 1, 2007) ("Treating physicians must be identified as expert witnesses pursuant to Rule 26(a)(2)(A).").

33. KIMPFLEN ET AL., supra note 32.

34. Cohen \& Jacxsens, supra note 32.

35. KIMPFLEN ET AL., supra note 32. See, e.g., NGO v. Standard Tools \& Equip., Co., Inc., 197 F.R.D. 263 (D. Md. 2000).

36. Dreiband, supra note 2, at 295. 2009).

37. Aumand v. Dartmouth Hitchcock Med. Ctr., 611 F. Supp. 2d 78, 88 (D.N.H.

38. Id.

39. Kirkpatrick v. Pfizer, Inc., No. CIV-09-92-C, 2009 WL 1290735, at *2-3 (W.D. Okla. May 6, 2009). 
The court found that the plaintiff's expert need not be disclosed as an expert because he was the plaintiff's "long-term, treating physician and his testimony [was] based on that history., ${ }^{40}$ However, the court restricted the physician's testimony to "his treatment of [the plaintiff] and any observations he made during that treatment," as well as "medical testimony to explain his treatment." Further, he could "not offer opinions which extend[ed] beyond the scope of his treatment of [the] [p]laintiff].",11

Federal courts following a broader approach allow a treating physician's fact testimony to encompass "any testimony based on the physician's care and treatment of the patient," and it is "[o]nly when the treating physician's proposed testimony goes outside of that broadly defined scope [that] disclosure under Rule 26(a) (2)(A) is required." ${ }^{, 42}$ For instance, in distinguishing whether a treating physician testified as a fact witness or an expert witness, the court in Jones v. Greyhound Lines, Inc. concluded that "a physician who testifies on information and opinions developed and drawn during the treatment of the party as a patient is considered to be an ordinary fact witness rather than an expert." line test" existed, the court found that it "must look to whether the medical opinions, conclusions and observations being offered by the treating physician necessarily played a role in his or her care and treatment of the plaintiff." ${ }^{, 44}$ Accordingly, the court concluded that it could not give the plaintiff "any advance determination" as to the necessity of expert reports. ${ }^{45}$

\section{After Designation as an Expert, Should a Report Be Produced?}

After designating the treating physician as an expert, courts also disagree as to whether an expert report needs to be produced. ${ }^{46}$ Some courts require a report only when a treating physician is testifying to causation, prognosis, and future disability. ${ }^{47}$ Other courts find that as long as the treating physicians' testimonies are based on personal knowledge, there is no need to produce a report. ${ }^{48}$ One additional approach declares that whether a report needs to be provided depends on the extent of the treating physi-

40. Id. at *2.

41. Id.

42. Cohen \& Jacxsens, supra note 32.

43. Jones v. Greyhound Lines, Inc., No. 08-1185-MLB-DWB, 2009 WL 2195760, at *3 (D. Kan. July 22, 2009) (citations omitted).

44. Id.

45. Id. at *4-5 (citations omitted); Cohen \& Jacxsens, supra note 32.

46. Rosenthal, supra note 29 , at 251 ("[T] federal courts on whether a treating physician providing expert testimony is required to provide an expert report in advance of testifying under Rule 26(a)(2)(B).").

47. Kimpflen, supra note 32. See, e.g., Griffith v. Ne. Ill. Reg'l Commuter R.R., 233 F.R.D. 513,516 (N.D. Ill. 2006).

48. Kimpflen, supra note 32. See, e.g., Hall v. Sykes, 164 F.R.D. 46, $48-49$ (E.D. Va. 1995); Salas v. United States, 165 F.R.D. 31, 33-34 (W.D.N.Y.1995). 
cian's testimony. ${ }^{49}$ The issue has even caused splits amongst district courts within the same court of appeals. ${ }^{50}$

\section{a. Expert report required only when testifying to causation, progno-} sis, and/or future disability

Some districts only require an expert report when a treating physician opines as to causation, prognosis, or future disability. ${ }^{51}$ For instance, in Upchurch $v$. Hester, the court found that whether a treating physician must provide an expert report depended upon the "substance of the testimony" as opposed to "the status of the witness." 52 Thus, a treating physician whose testimony "reaches beyond the basic facts learned during the treatment of a patient, and extends to typical opinion testimony," must produce an expert report. $^{53}$

In United States v. Henderson, the Eleventh Circuit held that "[a] treating physician is not considered an expert witness if he or she testifies about observations based on personal knowledge, including the treatment of the party." begins to answer hypothetically, as the essential difference between expert and lay witnesses is that an expert may be asked hypothetical questions. . $^{55}$

In Bengston v. Bazemore, the court found that Rule 26 centered "not on the status of the witness, but rather the substance of the testimony." treating physician testifying to his or her opinions concerning "the care and treatment of a patient" does not necessitate an expert report. ${ }^{57}$ Thus, no report needs to be produced when a treating physician testifies to the existence or the cause of a patient's injury, but a report is necessary when a treating physician's testimony "extends beyond the facts disclosed during care and treatment of the patient." $" 58$

In Brooks v. Union Pacific Railroad Company, the Eighth Circuit dis-

49. See, e.g., Thomas v. Consol. Rail Corp., 169 F.R.D. 1, 2 (D. Mass. 1996); Gonzalez v. Exec. Airlines, Inc., 236 F.R.D. 73, 75-79 (D.P.R. 2006).

50. See, e.g., Robbins v. Ryan's Family Steak Houses E., Inc., 223 F.R.D. 448, 453 (S.D. Miss. 2004). See also Mass. ConTINuING Legal EduC., INC., THE District CouRT SPEAKS: DisTRICT OF MASSACHUSETTS § 2.1.1 (6th ed. 2011), available at DCS MA-CLE 7.

51. See, e.g., Upchurch v. Hester, No. CIVA 05-252 JJF, 2006 WL 3020772, at *2 (D. Del. Oct. 23, 2006) (citation omitted); Allen v. Parkland Sch. Dist., 230 Fed. App'x. 189, 194 (3rd Cir. 2007); United States v. Henderson, 409 F.3d 1293, 1299-1301 (11th Cir. 2005).

52. Upchurch, No. CIVA 05-252 JJF, 2006 WL 3020772, at *2 (citation omitted).

53. Id. Accord Allen, 230 Fed. App'x. at 194.

54. Henderson, 409 F.3d 1293 at 1300 (quoting Davoll v. Webb, 194 F.3d 1116, 1138 (10th Cir.1999)).

55. Id.

56. Bengston v. Bazemore, No. 3:06-CV-569-MEF, 2007 WL 3307204, at *2 (M.D. Ala. Nov. 6, 2007).

57. Id.

58. Id. (citation omitted). 
tinguished between a treating physician testifying "as a lay witness when describing a medical condition," and a treating physician offering an opinion as to causation. ${ }^{59}$ Thus, when a treating physician offered testimony "not merely to explain [the plaintiff's] medical condition" but also "to explain causation of [the plaintiff's] condition," that causation opinion "brought his testimony within Rule 702 and Rule 26(a)(2)," and a report was thus required. ${ }^{60}$

While this requirement may lead to more certainty as to where to draw the line between those needing to produce expert reports and those that do not, patients may be prejudiced if a doctor who is not thought to initially need to produce an expert report later discovers he or she must testify as to causation. These necessary witnesses may be banned from testifying even when there would be no unfair prejudice to opposing sides.

\section{b. Depends on the extent of the treating physician's testimony}

Several courts have proposed that whether a treating physician is labeled as a fact witness or an expert depends upon the extent of his testimony. ${ }^{61}$ In these jurisdictions, the physician's fact testimony is "limited only to the physician's observations and actions in caring for the patient.,62 Consequently, a Rule 26(a)(2)(A) disclosure would be necessary "even where the physician would be called upon to explain his or her diagnosis and prognosis for the patient." ${ }^{, 63}$ For example, in Downey v. Bob's Discount Furniture Holdings, Inc., the First Circuit concluded that because an alleged expert's "opinion testimony [arose] not from his enlistment as an expert but, rather, from his ground-level involvement in the events giving rise to the litigation," he fell "outside the compass of Rule 26(a)(2)(B)."64

In Thomas $v$. Consolidated Rail Corporation, the court found that an expert report was required of a treating physician testifying beyond observations made during his treatment of a plaintiff because he testified "at least in part, not merely based on observations made during the course of treatment, but on professional expertise going beyond treatment per se."65 Accordingly, a treating physician who "formulated opinions going beyond what was necessary to provide appropriate care for the injured party steps

59. Brooks v. Union Pac. R.R. Co., 620 F.3d 896, 900 (8th Cir. 2010).

60. Id. at 900 .

61. Cohen \& Jacxsens, supra note 32 (finding that "to the extent that a treating physician testifies only to the care and treatment of a patient, the physician is not a 'specially employed' expert, and is not required to produce a written report prior to the admission of his or her testimony in an action by the patient").

62. Id.

63. Id. See generally Fielden v. CSX Transp., Inc., 482 F.3d 866, 870-72 (6th Cir. 2007) (discussing various strategies taken by different federal courts).

64. Downey v. Bob's Disc. Furniture Holdings, Inc., 633 F.3d 1, 6 (1st Cir. 2011).

65. Thomas v. Consol. Rail Corp., 169 F.R.D. 1, 2 (D. Mass. 1996). 
into the shoes of a retained expert," thus requiring an expert report. ${ }^{66}$

In Gonzalez v. Executive Airlines, Inc., the court concluded that a treating doctor was not required to produce an expert report when the physician testified only to the care and treatment of a patient. ${ }^{67}$ Nevertheless, those opinions that treating physicians developed independently from their examination of the patient "constitute[d] expert opinion testimony and [were] subject to the more stringent requirements of Rule $26(\mathrm{~b})(4)(\mathrm{c}) .{ }^{, 68}$

While this strategy does create a clear, bright-line standard, it also creates potential complications. It creates a report requirement for those treating physicians who testify as to causation or prognosis, even though these doctors may have opined as to causation or prognosis in their course of treatment of a patient. In addition, it may not easily be enforced, as it may be difficult to tell when a doctor goes beyond what was necessary to step into the shoes of a retained expert.

c. No need to produce an expert report when treating physician's testimony based upon personal knowledge

A number of courts conclude that a treating physician may testify as to causation and prognosis without producing an expert report, provided that his testimony is based on his or her personal knowledge or observations made during the course of care and treatment, and so long as the physician was not "specially retained in connection with the litigation or for trial."69 However, when the doctor opines "beyond the facts disclosed during the care and treatment of the patient" and "is specifically retained to develop opinion testimony, he or she is subject to the report requirement."

In Salas $v$. United States, the court concluded that if the physician's opinions were acquired directly through his treatment of the plaintiff, then he was not required to submit a written report. ${ }^{71}$ Accordingly, a treating physician's opinions on causation and permanency do not necessarily render him or her an expert needing to produce a report simply because he or she "consider[ed] not just the plaintiff's diagnosis and prognosis, but also the cause." 72 Instead, "[t]he relevant question is whether [the] treating physicians acquired their opinions as to the cause of the plaintiff's injuries directly through their treatment of the plaintiff."73

In Peck v. Hudson City School District, the court found that the Rule

66. Id. See also Goodman v. Staples the Office Superstore, LLC, No. 10-15021, 2011 U.S. App. LEXIS 8979, at *19-21 (9th Cir. May 3, 2011).

67. Gonzalez v. Exec. Airlines, Inc., 236 F.R.D. 73, $75-79$ (D.P.R. 2006).

68. Id. at 79 .

69. Kimpflen, supra note 32.

70. Id.

71. Salas v. United States, 165 F.R.D. 31, 33 (W.D.N.Y. 1995).

72. Id.

73. Id. at 33-34. 
26(a)(2)(B) written report requirement applies when a doctor's opinion testimony stretches "beyond the facts disclosed during care and treatment of the patient, and the doctor is specifically retained to develop opinion testimony." H4 However, in so far as a "treating physician testifies only to the care and treatment of the patient," he or she is not deemed "a "specially employed' expert and is not subject to the written report requirements of Rule $26(a)(2)(B)$, notwithstanding that the witness may offer opinion testimony under [the Federal Rules of Evidence]."

In Moore v. McKibbon Brothers, Inc., the court found that true treating physicians should not be required to submit an expert report, as the Rule $26(a)(2)(B)$ requirement only implicated those experts who were "specifically retained" to testify as experts. ${ }^{76}$ Treating physicians generally "become involved in the matter not as a witness, but in order to treat the Plaintiff," because these "[t]reating physicians [were] really fact witnesses whose testimony flow[ed] from information they learned during the course of their treatment."77 Expert reports were not necessary provided that the treating physicians' "testimony relate[d] to information learned during the scope of their treatment," which "include[d] observations and opinions about diagnosis, causation, treatment, prognosis, costs of treatment and estimates of future such costs.",78

In Hall v. Sykes, the court concluded that a treating physician who "form[ed] an opinion of the causation of an injury to a patient and the prognosis of the patient's condition during the treatment," was not required to submit a Rule 26(a)(2)(B) report. ${ }^{79}$ Conversely, if that doctor, "even though he may be a treating physician," was "specially retained or employed to render a medical opinion based on factors that were not learned in the course of the treatment of the patient," then an expert report from that physician would be necessary. ${ }^{80}$ Notably, however, just because a treating physician is paid a fee does not automatically establish that treating physician as "a specially retained or employed expert" who must prepare an expert report. $^{81}$

In Davoll v. Webb, the Tenth Circuit found that "[a] treating physician is not considered an expert witness if he or she testifies about observations based on personal knowledge, including the treatment of the party." 82 Thus,

74. Peck v. Hudson City Sch. Dist., 100 F. Supp.2d 118, 121 (N.D.N.Y. 2000).

75. Id. (citation omitted).

76. Moore v. McKibbon Bros., Inc., 42 Fed. R. Serv. 3d 751, at *1 (E.D.N.C. 1999).

77. Id.

78. Id. at *2.

79. Hall v. Sykes, 164 F.R.D. 46, 48 (E.D. Va. 1995).

80. Id. at $46,48-49$.

81. Id. at 48 .

82. Davoll v. Webb, 194 F.3d 1116, 1138 (10th Cir. 1999) (citations omitted). See also Weese v. Schukman, 98 F.3d 542, 550 (10th Cir. 1996) (finding that a physician's lay opinions "were based on his experience as a physician and were clearly helpful to an under- 
even a treating doctor testifying as a lay witness, "may state 'expert' facts to the jury in order to explain his testimony" and "should be given loose rein to state what are truly facts, even if they are 'expert' facts." under Rule 701, each opinion the lay witness doctor gave was "based on his experience as a physician" and was "clearly helpful to an understanding of his decision making process in the situation.",84

In Wreath $v$. United States, the court concluded that treating physicians who testified "only to the care and treatment afforded to a party" were intentionally excluded from the expert report requirement pursuant to Fed. R. Civ. P. 26(a)(2)(B). ${ }^{85}$ Those treating physicians who testify only "to the care and treatment of his/her patient," are not considered specially retained experts even though they advance opinion testimony under Fed. R. Evid. 702,703 , or $705 .^{86}$ Conversely, a doctor whose "proposed opinion testimony extends beyond the facts made known to him during the course of the care and treatment of the patient," and who is "specially retained to develop specific opinion testimony," must produce a Fed. R. Civ. P. 26(a)(2)(B) expert report. $^{87}$

In Farris v. Intel Corp., the court found that the Rule 26(a)(2)(B) report requirement "does not apply to treating physician[s]," because they are "hybrid witness[es]," who may "testify to "fact opinions," including "causation, diagnosis, prognosis, and the extent of Plaintiff's disability or injury derived from his observations and treatment." ${ }^{, 88}$ However, the extent of a treating physician's opinion testimony is limited, as he or she is "not permitted to provide expert testimony regarding any opinion he [or she] formed based on information learned outside of, and not related to, [the patient's] treatment" if they do not produce an expert report. ${ }^{89}$

In Hawkins $v$. Graceland, the Sixth Circuit held that the necessity of an expert report by a treating physician depended upon "the substance of the treating physician's testimony rather than his or her status" and to not classify a treating physician as an expert under Rule 26 "simply by virtue of his or her expertise." 90 The physician is thus not categorized as an expert witness "if he or she testifies about observations based on personal knowledge, including the treatment of the party." only considered an expert subject to the Rule 26 requirements when he

standing of his decision making process in the situation").

83. Id. (citations omitted).

84. Id. (citations omitted).

85. Wreath v. United States, 161 F.R.D. 448, 449 (D. Kan. 1995).

86. Id. at 450 .

87. Id.

88. Farris v. Intel Corp., 493 F. Supp. 2d 1174, 1179-80 (D.N.M. 2007).

89. Id.

90. Hawkins v. Graceland, 210 F.R.D. 210, 211 (W.D. Tenn. 2002). See also Barnes v. CUS Nashville, LLC, No. 3:09-cv-0764, 2011 U.S. Dist. LEXIS 46457, *27-37 (M.D. Tenn. Apr. 29, 2011).

91. Id. (quoting Davoll v. Webb, 194 F.3d 1116, 1138 (10th Cir. 1999)). 
opines "beyond the facts disclosed during care and treatment of the patient," and he or she "is specially retained to develop opinion testimony." larly, in Mohney v. USA Hockey, Inc., the Sixth Circuit held that when a treating physician testifies as to his or her own personal knowledge, he or she may testify without being designated an expert. ${ }^{93}$ When the physician uses outside resources to inform him or herself, such as watching a videotape of the incident, ${ }^{94}$ that doctor must be disclosed as an expert. ${ }^{95}$

In Fielden v. CSX Transportation, Inc., the court did not select a particular method to determine the status of treating physicians, but the Sixth Circuit discussed the strategies utilized by other courts. ${ }^{96}$ The court found that this case was not inconsistent with those jurisdictions that look to fundamental fairness of the circumstances because the scope of the testimony was of no surprise to the opposing party. ${ }^{97}$ The court also concluded that this case was not "inconsistent with those that have focused on the content of the physician's testimony," because both parties were aware of the content of the physician's testimony. ${ }^{98}$ The Sixth Circuit additionally concluded that a physician relying only upon his ordinary medical training would not qualify as an expert. ${ }^{99}$ Finally, the court found that it was consistent with other courts who determine the status of experts by "whether a treating physician relies on tests, documents, books, videos, or other sources that the physician did not rely upon during his or her treatment of the patient" because there was "no evidence that [the physician] based his opinion as to the cause of [the] injury on any source other than his treatment."100 The Sixth Circuit, therefore, distinguished Mohney because evidence existed that the treating physician "reached his conclusion about the cause of [the

92. Id. See also Ridder v. City of Springfield, 108 F.3d 1377, 1997 WL 117024, at *4 (6th Cir. Mar. 13, 1997) (upholding an order permitting plaintiff's treating physician to testify without Rule 26(a)(2)(B) expert report disclosures "so long as they do not purport to testify beyond the scope of their own diagnosis and treatment"); Mall v. Am. Honda Motor Co., No. 06-12332, 2007 WL 1452941, at *1 (E.D. Mich. May 17, 2007) (holding that treating physicians who were designated by plaintiff as experts were "not subject to the requirements of Fed. R. Civ. P. 26(a)(2)(B) regarding reports"). But c.f. Harville v. Vanderbilt Univ., Inc., 95 F. App'x. 719, 724-725 (6th Cir. 2003) (report requirement focused on the "substance of the testimony, rather than the status of the witness," and hinted that testimony regarding the standard of care fell "within the category of expert testimony that is required to be disclosed under Rule 26").

93. Mohney v. USA Hockey, Inc., 138 F. App'x. 804, 811 (6th Cir. 2005).

94. Id. (concluding that because a treating physician "clearly was opining as to the manner in which [plaintiff was injured] . . . based in part on his viewing of the video," and there was "no evidence that [the doctor] reached the same conclusions regarding causation at the time he treated [plaintiff]," it was reasonable to conclude he was an expert witness subject to the expert report disclosure requirements).

95. Id. at $810-11$.

96. Fielden v. CSX Transp., Inc., 482 F.3d 866, 870-72 (6th Cir. 2007).

97. Id.

98. Id. at 871-72.

99. Id. at 872 .

100. Id. 
patient's] injuries at the time of the treatment."101

This standard is more patient-friendly, as it allows more treating physicians to testify without the burden of an expert report. However, this standard may result in oversimplifications, for requiring a report from these doctors may result in unfair prejudice to patients because a true treating physician may consult outside information in order to more adequately and efficiently treat his or her patient. On the other hand, opposing parties could argue that unfair prejudice exists because these doctors are technically providing scientific knowledge described under F.R.E. 702 without producing an expert report.

\section{d. Splits within district courts of the same court of appeals and even the same district courts}

Because the courts of appeals have employed various methods to determine whether a treating physician needs to produce a report, it is not surprising that there are even splits of opinions amongst the district courts within each court of appeal, including the Fifth Circuit, or even the district courts, such as the District of Massachusetts. Though the Fifth Circuit suggested that treating physicians generally do need to be designated as experts, ${ }^{102}$ some district courts have held that the designation of treating physicians as experts is mandatory, ${ }^{103}$ while others have held that treating physicians only need to be disclosed when the expert is retained to develop an opinion. ${ }^{104}$

For example, in Robbins v. Ryan's Family Steak Houses East, Inc., the court found that in the Southern District of Mississippi, "treating physicians must be designated as expert witnesses[,] they must be so designated in a timely manner, ${ }^{, 105}$ and must produce a report. ${ }^{106}$ Conversely, in Young $v$. U.S. the court determined that under Rule 26, a treating physician "generally must be considered an ordinary fact witness, and should not be considered an expert unless the physician has been specifically retained to develop an expert opinion." 107

101. Id. at 871 .

102. Hamburger v. State Farm Mut. Auto. Ins. Co., 361 F.3d 875, 883 (5th Cir. 2004) ("Hamburger first explains that he failed to timely designate Dr. Fitzgerald because his 'counsel did not believe that a treating physician was the type of witness from whom an expert report was necessary.' While this explanation addresses why Hamburger did not obtain and serve a written report from Dr. Fitzgerald pursuant to Rule 26(a)(2)(B), it does not address why Hamburger failed to timely designate Dr. Fitzgerald as a testifying expert under Rule 26(a)(2)(A), and no other explanation is given.").

103. See, e.g., Robbins, 223 F.R.D. at 453; Bunch v. Metro. Cas. Ins. Co., No. 5:10-cv104-DCB-JMR, 2011 U.S. Dist. LEXIS 40378, at *2-5 (S.D. Miss. Apr. 6, 2011).

104. See, e.g., Young v. United States, 181 F.R.D. 344, 346 (W.D. Tex. 1997).

105. Robbins, 223 F.R.D. at 453.

106. Id.

107. Young, 181 F.R.D. at 346. 
Interview questions posed to judges in the District of Massachusetts highlight how prickly this problem can be within the same district court. ${ }^{108}$ For example, Judge Earns "do[es] not require expert reports from treating physicians, only the production of the relevant medical records."109 Similarly, Judge Gorton does not require expert reports to be disclosed for physicians testifying as both treating physician and expert witness, and Judge Stearns does not require expert reports so long as it is "made clear by the offering party prior to any deposition that the treating physician will be asked to give expert opinions at trial." 110 On the other hand, Judges Neiman, Hillman, Gertner, Tauro, and O'Toole require reports to be disclosed for physicians testifying as both treating physician and expert witness. ${ }^{111}$ The judges also had varying answers when asked about whether they "strictly limit the scope of expert testimony at trial matters explicitly disclosed in expert reports," or "where appropriate permit an expert to testify on matters related to but not specifically described in the reports." 112 For instance, Judge Young assures experts "very strictly" stick to their expert reports. ${ }^{113}$ On the other hand, Judge Gorton allows an expert to testify outside their reports where appropriate, and Judge Saris "do[es] not limit the expert testimony to the report if there has been a deposition."114

Ultimately, it is clear that no uniform standard exists amongst the courts of appeals, and there is even division amongst the district courts within the courts of appeals and their district courts. However, it appears that over the last few years, courts have gravitated towards allowing a treating physician to testify without producing an expert report, even as to causation and prognosis, so long as his testimony is based upon the treating physician's course of treatment of the patient. ${ }^{115}$

\section{Seventh Circuit's Management of Treating Physicians}

This division and uncertainty also exists in the Seventh Circuit be-

108. MASS. CONTINUING LEGAL EdUC., INC., supra note 50.

109. Id.

110. Id.

111. Id.

112. Id.

113. Id.

114. Id.

115. Taylor v. Union Pacific R.R. Co., No. 09-123-GPM, 2010 WL 5463132, at *2 (S.D. Ill. Dec. 29, 2010) ("Typically, courts do not require a treating physician to provide an expert report where the physician's testimony about causation, prognosis, and the extent of disability is based on his or her treatment of a party."). See, e.g., Kansky v. Showman, No. 3:09cv1863, 2011 U.S. Dist. LEXIS 38814, *13-15 (M.D. Penn. Apr. 11, 2011); Goodman v. Staples the Office Superstore, LLC, No. 10-15021, 2011 U.S. App. LEXIS 8979, at *1921 (9th Cir. May 3, 2011); Barnes v. CUS Nashville, LLC, No. 3:09-cv-0764, 2011 U.S. Dist. LEXIS 46457, *27-37 (M.D. Tenn. Apr. 29, 2011); Bunch v. Metro. Cas. Ins. Co., No. 5:10-cv-104-DCB-JMR, 2011 U.S. Dist. LEXIS 40378, at *2-5 (S.D. Miss. Apr. 6, 2011). 
cause the court has yet to provide clear guidance on treating physicians, and district courts have thus been forced to elect their own strategies. The leading Seventh Circuit opinion decided after the 1993 Rule 26 amendment was Musser v. Gentiva Health Services. ${ }^{116}$

In Musser v. Gentiva Health Services, the Seventh Circuit examined a medical malpractice claim in which a Northern District of Indiana judge had excluded the plaintiffs' treating physician because the plaintiffs had failed to disclose the treating physician as an expert. ${ }^{117}$ The plaintiffs had disclosed the treating physicians as fact witnesses, and the defendant possessed their medical records and had the opportunity to depose the doctors, but the Seventh Circuit determined that this was not sufficient to allow the treating physicians to testify. ${ }^{118}$ Instead, the court concluded that a treating physician should be disclosed as an expert when his or her testimony "consists of opinions based on 'scientific, technical, or other specialized knowledge' regardless of whether those opinions were formed during the scope of interaction with a party prior to litigation." less found that a report is not always required of a treating physician, yet did not provide any further direction on the matter. ${ }^{120}$ The Seventh Circuit simply stated that "some district courts have suggested that if the Rule 26(a)(2)(A) testimony exceeds the scope of treatment and ventures into more general expert opinion testimony, a report may be necessary."121

Subsequently, in Blameuser v. Hasenfang, the Seventh Circuit emphasized that it has "never held that treating physicians must file expert reports." The court ultimately held that no expert report was required of a treating physician who based his testimony primarily on the medical chart he prepared and his treatment and diagnosis, which he reached during his treatment. ${ }^{123}$ However, the Seventh Circuit failed to offer any further suggestions on treating physicians. ${ }^{124}$ Judge Easterbrook noted that "[a]n interesting question is what to do with a treating physician who proposes to testify in the manner of a hired expert, i.e., offering an opinion regarding what might have happened to the patient that does not rely on that physician's personal treatment of the patient."125

In Meyers v. National R.R. Passenger Corp. (Amtrak), the Seventh

116. Musser v. Gentiva Health Servs., 356 F.3d 751 (7th Cir. 2004).

117. Id. at 754-55.

118. Id. at 757-58 ("Formal disclosure of experts is not pointless" because "[k]nowing the identity of the opponent's expert witnesses allows a party to properly prepare for trial[, and the defendants] should not be made to assume that each witness disclosed by the [plaintiffs] could be an expert witness at trial.").

119. Id. at 757 n.2.

120. Id. at 758 n.3.

121. Id.

122. Blameuser v. Hasenfang, 345 F. App'x. 184, 186 (7th Cir. 2009).

123. Id. at 187.

124. Id. at $186-87$.

125. Id. at 187 . 
Circuit specifically addressed whether a formal report under Rule 26(a)(2)(B) was necessary for those treating physicians "[providing] an expert opinion as to causation . . . when the subject of such opinion was not determined at the time of treatment." ${ }^{, 26}$ The court concluded that a treating physician, who provided expert testimony regarding causation but did not form that position in the course of his or her treatment of plaintiff, should be considered a retained or specially employed expert needing to provide a Rule 26(a)(2) expert report. ${ }^{127}$ Because the treating physicians "prepared letters with opinions as to the causation of [the plaintiff's] injuries at the request of [the plaintiff's] attorney, specifically for the purpose of litigation," and there was no evidence "suggesting that either doctor previously considered or determined the cause of [the plaintiff's] injuries during the course of treatment," the Seventh Circuit concluded that the plaintiff "was required to provide a proper expert report under Rule 26(a)(2).",128

Additionally, in Banister v. Burton, the Seventh Circuit found that no report was required because the doctor at issue was the treating physician, and he was not retained. ${ }^{129}$ The court concluded that Meyers was distinguishable from Banister because Meyers concerned a physician's opinion "as to the cause of an injury determined for the purpose of litigation," which differs from a judgment "as to the effects of the injury at the time of treatment." 130 Moreover, the physician at issue "did not formulate his opinion at the request of the [party] as the doctors in Meyers had." instead given "the same testimony at the state criminal trial and when he was deposed by the parties." 132

Thus, the Seventh Circuit has left open whether a treating physician is in fact a witness or an expert because it never affirmatively or absolutely held that treating physicians were experts. ${ }^{133}$ Furthermore, the court failed to definitively answer whether a report should be required of a treating physician who formed his opinion within the course of treatment of the patient. ${ }^{134}$ Due to the lack of direction from the Seventh Circuit, there remains

126. Meyers v. Nat'l R.R. Passenger Corp. (Amtrak), 619 F.3d 729, 734 (7th Cir. 2010).

127. Id. at $734-35$ (citations omitted).

128. Id. at 735; accord Aurand v. Norfolk S. Ry. Co., Nos. 3:08-CV-398-PPS, 3:08-CV-480-PPS, 3:08-CV-485-PPS2011, 2011 WL 2938447, at *11-13 (N.D. Ind., July $18,2011)$.

129. Banister v. Burton, 636 F.3d 828, 833 (7th Cir. 2011).

130. Id.

131. Id. See also Allison v. United States, No. 09-cv-3341, 2011 WL 1627083, at *4 (C.D. Ill. Apr. 28, 2011) (concluding that because the expert had formed his opinion "after treatment had concluded, probably at the request of counsel," Banister required an expert report).

132. Banister, $636 \mathrm{~F} .3 \mathrm{~d}$ at 833 .

133. Blameuser, 345 F. App'x. at 186 (noting that the Seventh Circuit has "held that in some circumstances, treating physicians must be disclosed as experts pursuant to Rule 26(a)(2)(A)" (emphasis added)).

134. Musser, 356 F.3d at 757 n.3. See also Termini v. Bd. of Lake Cnty. Comm'rs, 
a split amongst the federal district courts within the Seventh Circuit. ${ }^{135}$

\section{Being Retained Creates a Report Requirement}

Some district courts in the Seventh Circuit have held that whether a report is required depends on whether a treating physician was retained. For instance, in Osuji v. City of Chicago, the court held that "[b]ecause the doctors were not retained or specially employed, plaintiff need not have submitted a report under Rule 26(a)(2)(B)."136 In addition, in Logan v. Illinois Central Railroad Co., the court based its decision to require an expert report partly upon the appearance that the treating physician had been retained. $^{137}$

\section{Causation Creates a Report Requirement}

Several judges have held that a treating physician must provide a report when he or she provides testimony beyond his or her observations, diagnosis, or treatment and is expected to include opinions on issues such as causation, prognosis, and permanency. ${ }^{138}$ For example, in Tzoumis $v$.

No. 2:09-CV-10-PPS-PRC, 2010 WL 2674507, at *3 (N.D. Ind. June 29, 2010) ("[T]he Seventh Circuit Court of Appeals has yet to definitely decide whether a treating physician must provide an expert report under Rule 26(a)(2)(B) in order to testify as to causation, future medical care and prognosis, or permanency of injury or disability.").

135. McCloughan v. City of Springfield, 208 F.R.D. 236, 241-42 (C.D. Ill. 2002) (discussing the different methods utilized by district courts in the Seventh Circuit). See also Eagle Servs. Corp. v. H20 Indus. Servs., Inc., No. 2:02-CV-36-PRC, 2005 WL 5988646, at *2 (N.D. Ind. Sept. 30, 2005) (discussing the different strategies of federal courts in the Seventh Circuit). At times, it is unclear which strategy courts are employing. See, e.g., Rahoi v. Sirin, 252 F.R.D. 464, 468-69 (W.D. Wis. 2008) (concluding that the testimony from the patient's treating physicians that "might offer outside the scope of their treatment of plaintiff must be barred" because it was likely that the doctors "would be asked to testify as experts about the standard of care for a torn rotator cuff and how plaintiff's treatment in prison related to that care;" yet, allowing the treating physicians to testify so long as they did not "present testimony outside the scope of his treatment of plaintiff").

136. Osuji v. City of Chicago, No. 02 C 4199, 2005 WL 1799277, at *6 (N.D. Ill. July 26, 2005).

137. Logan v. Illinois Cent. R.R. Co., No. 305-CV-902-DRH, 2006 WL 3841593, at *4 (S.D. Ill. Dec. 14, 2006) review denied, order aff'd sub nom. Logan v. Illinois Cent. R. Co., Inc., No. 05CV0902 DRH, 2007 WL 30539 (S.D. Ill. Jan. 4, 2007) (finding that the plaintiff's doctor was a retained expert requiring a Rule 26(a)(2)(B) report because the expert disclosure went "beyond medical records, testing, examinations that were performed during the treatment of a plaintiff," because of the physician's "reference to texts, documents, and reference books within her profession; market surveys, job market analyses, government publications").

138. Eagle Servs Corp., No. 2:02-CV-36-PRC, 2005 WL 5988646, at *4. See, e.g., Sowell v. Burlington N. and Santa Fe Ry. Co., No. 03 C 3923, 2004 WL 2812090, at *3 (N.D. Ill. Dec. 7, 2004); Brandon v. Village of Maywood, 179 F. Supp. 2d 847, 859 (N.D. Ill. 2001); Rebolledo v. Herr-Voss Corp., 101 F. Supp. 2d 1034, 1039 (N.D. Ill. 2000); Barrett v. Int'l Armaments, Inc., No. 95 C 2690, 1999 WL 199253, at *6 (N.D. Ill. Mar. 31, 1999); Murray v. Chicago Transit Auth., No. 97 C 7923, 1999 WL 49355, at*1 (N.D. Ill. Jan. 29, 1999); Schoolman v. UARCO, Inc., No. 94 C 5598, 1999 WL 47124, at *3 (N.D. Ill. 
Tempel Steel Co., a Northern District of Illinois judge held that "[a] treating physician is not automatically an 'expert' witness simply because he is a doctor." Even when he is not disclosed as an expert, a treating physician "may still testify regarding his observations made during the course of treatment and on matters in his personal knowledge."139 However, once a physician's testimony "goes beyond his personal observations, treatment, and diagnosis," it "slips over into matters normally considered 'expert' testimony," and hence "may be barred."140

In Griffith v. Northeast Illinois Regional Commuter R.R., a Northern District of Illinois judge held that a treating physician was not required to produce a written report under Fed. R. Civ. P. 26 when the physician limited his testimony to matters dealing with the care and treatment of a patient. ${ }^{141}$ However, when the treating physician opines as to causation, prognosis, or future disability, "[h]e is going beyond his personal involvement in the facts of the case and giving an opinion formed because there is a lawsuit" and therefore must comply with the requirements of Fed. R. Civ. P. 26(a)(2)(B). ${ }^{142}$

In Bell v. Columbia St. Mary's Hosp. Milwaukee, Inc., the plaintiff argued that the treating physician's treatment records should suffice instead of a report because "the defendants [could] effectively prepare for cross examination through reviewing the treating physicians' treatment records and deposing the doctors." ${ }^{143}$ However, since the treating physicians were to be "called upon to offer expert testimony regarding their opinions drawn from their treatment of [the patient], the prognosis of Bell's injury, and potentially to offer testimony regarding the causation of [the plaintiff's] injury and future disability," an Eastern District of Wisconsin judge required these treating physicians to provide Rule 26(a)(2)(B) reports. ${ }^{144}$

Furthermore, a few Northern District of Indiana judges have held that treating physicians must be designated as experts, and whether a treating physician needs to produce an expert report depends on the extent of his testimony: if a physician testifies beyond his scope of treatment to causation, prognosis, or permanency, he or she will be required to produce an expert report. ${ }^{145}$ For instance, in Eagles Services Corp. v. H2O Industrial

Jan. 20, 1999); Zarecki v. Nat'l R.R. Passenger Corp., 914 F. Supp. 1566, 1573 (N.D. Ill. 1996) (holding that a treating physician could not testify regarding causation because he was not disclosed as an expert pursuant to Rule 26(a)(2), and the doctor was "purporting to speak as an expert on these issues based on some unspecified body of professional knowledge").

139. Tzoumis v. Tempel Steel Co., 168 F. Supp. 2d 871, 876 (N.D. Ill. 2001).

140. Id. 2006).

141. Griffith v. Ne. Illinois Reg'l Commuter R.R., 233 F.R.D. 513, 516-19 (N.D. Ill.

142. Id. at 518 .

143. Bell v. Columbia St. Mary's Hosp. Milwaukee, Inc., No. 07-CV-81, 2008 WL 163671 , at *3 (E.D. Wis. Jan. 16, 2008).

144. Id.

145. Matthew King, Doctor, Can I Get That in Writing? DTCI: Testifying Physicians Must Provide Written Reports for Opinions, IND. LAw., http://www.theindianalawyer.com/ 
Services, Inc., the court found "more persuasive the reasoning of those cases . . . disallowing causation testimony because [the expert's] testimony would go beyond her knowledge directly related to her involvement with the Plaintiff's business prior to the litigation and such opinions would be for the purpose of the litigation." 146

\section{Disclosure Depends on How the Information Was Obtained}

It seems that the majority of district courts within the Seventh Circuit are moving towards a standard that allows treating physicians to offer opinion testimony on causation, diagnosis, and prognosis of their patients without providing an expert report so long as their testimony is based upon their personal knowledge of the facts surrounding the injuries and treatment of the patient. ${ }^{147}$ For instance, in McCloughan v. City of Springfield, the court found that, plaintiff's treating physicians, who had not filed Rule 26 expertwitness disclosure reports, could offer opinions on causation, diagnosis and prognosis. ${ }^{148}$ Generally, no expert report was required of a treating physician provided that his or her "planned testimony was acquired, not in preparation for trial, but rather because he was an actor or viewer with respect to transactions or occurrences that are a part of the subject matter of the law-

doctor-can-i-get-that-in-writing-testifying-physicians-must-provide-written-reports-foropinions-beyond-personal-observations-and-treatment/PARAMS/article/23796 (last visited Oct. 30, 2011).

146. Eagle Servs. Corp. v. H20 Indus. Servs., Inc., No. 2:02-CV-36-PRC, 2005 WL 5988646, at *5 (N.D. Ind. Sept. 30, 2005). See also Colter v. Rockwell Automation, Inc., No. 3:08-CV-527 JVB, 2009 WL 7450978, at *3 (N.D. Ind. Nov. 18, 2009) (requiring that "treating physicians testifying to causation, prognosis, and permanency file expert reports satisfying the requirements of Rule 26(a)(2)(B)").

147. Martin v. CSX Transp., Inc., 215 F.R.D. 554, 556 (S.D. Ind. 2003) ("The majority of courts permit physicians to present their opinions formulated during the course of treating a patient."). See also Eagle Servs. Corp., No. 2:02-CV-36-PRC, 2005 WL 5988646, at *3; Taylor v. Union Pacific R. Co., No. 09-123-GPM, 2010 WL 5463132, at *2 (S.D. Ill. Dec. 29, 2010); Krischel v. Hennessy, 533 F. Supp.2d 790, 794-95 (N.D. Ill. 2008). See, e.g., Denson v. Ne. Ill. Reg'l Commuter R.R. Corp., No. 00 C 2984, 2003 WL 1732984, at *1 (N.D. Ill. Mar. 31, 2003) ("There is no indication that any of the three treating physicians from whom plaintiff may elicit expert opinions was retained or specially employed for that purpose," and thus "the report requirement does not apply for their testimony."); Zurba v. United States, 202 F.R.D. 590, 592 (N.D. Ill. 2001) (finding that "[d] eveloping an opinion as to the cause of the patient's injury based on a physical examination ... is 'a necessary part of treatment' and does not make the treating physician an expert," and that the "same may be true regarding the permanency of the plaintiff's condition"); Sircher v. City of Chicago, No. 97 C 6694, 1999 WL 569568, at *1-2 (N.D. Ill. July 28, 1999) (“[P]roposed opinion testimony [coming] from his knowledge acquired as a treating physician, is not someone from whom a Rule 26(a)(2)(B) formal report is required."); Crespo v. City of Chicago, No. 96 C 2787, 1997 WL 537343, at*3 (N.D. IIl. Aug. 22, 1997) (citation omitted) (concluding that treating physicians "may testify as to their personal knowledge of the patient," including "opinion[s] as to the cause of an injury based upon their examination of the patient or to the degree of injury in the future," because "[t]hese opinions are a necessary part of the treatment of the patient ... [and] do not make the treating physicians experts").

148. McCloughan v. City of Springfield, 208 F.R.D. 236, $240-42$ (C.D. Ill. 2002). 
suit." 149 The court concluded that "instead of focusing on whether a witness is an 'expert' under the Federal Rules of Evidence, the question, in reality, is: whether the witness whose opinion is sought to be elicited is someone from whom a report is required under Fed. R. Civ. P. ('Rule') 26(a)(2)(B)," or in other words, whether the witness "is retained or specifically employed to provide expert testimony in the case." $" 150$ As a result, a treating physician "may offer opinion testimony on causation, diagnosis, and prognosis without the prerequisite of providing a Rule 26(a)(2)(B) report."151

In Gary $v$. Alexander, the court considered whether reports were required of the plaintiff's treating physicians. ${ }^{152}$ Even though the court recognized that "a party must still disclose the treating physician as an expert witness under Rule 26(a)(2)(A)," it held that "Rule 26(a)(2)(B) does not apply to treating physicians who provide opinion testimony formulated in connection with treatment, including opinions on causation, diagnosis, and prognosis. $^{153}$

Similarly, in Osterhouse v. Grover, the court considered whether plaintiffs' treating physicians should be excluded from testifying because they did not produce expert reports. ${ }^{154}$ The court concluded that the plaintiffs' treating physicians were not retained because they were testifying "based on the medical records, testing, [or] examinations that were performed during the treatment of a plaintiff and not necessarily in anticipation of litigation."155 Further, there was no indication that the plaintiffs had "solicited the services of any of the doctors solely because they intended to file suit." 156 Moreover, testimony as to causation or prognoses generally failed to "elevate these doctors" to the status of a retained expert because it is not uncommon for a doctor to obtain information and to develop opinions regarding the "processes of an injury" as well as "the future ramifications of

149. Id. at 241 (citations omitted).

150. Id. (citations omitted).

151. Id. at 242.

152. Gary v. Alexander, No. 08-3241, 2009 WL 1162387, at *1 (C.D. Ill. Apr. 24, 2009).

153. Id. See also Dereak v. Don Mattox Trucking, LLC, 69 Fed. R. Serv. 3d 394, at *7 (C.D. Ill. Oct. 30, 2007) (concluding that because no expert reports were produced, treating physicians were "limited to the substance and opinions disclosed by Plaintiffs in the answers to interrogatories, in each witness's report and his or her records disclosed to Defendant, and in each witness's deposition testimony"); Ridings v. Riverside Med. Ctr., No. 05-2134, 2006 WL 1084323, at *1 (C.D. Ill. Apr. 25, 2006).

154. Osterhouse v. Grover, No. 3:04-cv-93-MJR, 2006 WL 1388841, at *1 (S.D. Ill. May 17, 2006). See also Williams v. Schram, No. 06-CV-00557-DRH, 2008 WL 2691887, at *3 (S.D. Ill. June 30, 2008) (finding that treating physicians were only "allowed to testify as to the treatment they have personally provided to plaintiff as a patient in their care," but could not "testify as to their opinions based on their review of any other doctor's treatment or recommendation").

155. Osterhouse, No. 3:04-cv-93-MJR, 2006 WL 1388841, at *3.

156. Id. 
an injury" during his or her course of treatment of a patient. ${ }^{157}$

Occasionally, some Southern District of Indiana judges have allowed treating physicians who were designated as experts to testify regarding causation, permanency, and prognosis without producing expert reports. ${ }^{158}$ Moreover, they have permitted treating physicians to opine as to causation, diagnosis, and prognosis without providing a Rule 26 report. ${ }^{159}$ For instance, in Martin v. CSX Transportation, Inc., Magistrate Judge Baker wrote that "[i]t is within the normal range of duties for a health care provider to develop opinions regarding causation and prognosis during the ordinary course of an examination," as "to properly treat and diagnose a patient, the doctor needs to understand the cause of a patient's injuries." ${ }^{160}$ As a result, a physician "whose proposed opinion testimony will come from his knowledge acquired as a treating physician, is not someone from whom a Rule 26(a)(2)(B) report is required."

Similarly, in McQuiston v. Helms, the court concluded that a physician "“whose proposed opinion testimony will come from his knowledge acquired as a treating physician, is not someone from whom a Rule $26(\mathrm{a})(2)(B)$ report is required." 162 Because the physician witness in McQuiston did not rely upon information gathered ex parte from the expert's treatment of the patient, no expert report was required. ${ }^{163}$

Without clear or conclusive guidance from the Seventh Circuit, the district courts have employed varying strategies to determine whether treating physicians must produce expert reports. Moreover, this lack of guidance has caused many judges within the same district courts to differ in managing the report requirement for treating physicians. However, recently courts appear to be gravitating toward a standard that requires no expert report unless the doctor has testified outside his or her course of treatment of the plaintiff.

157. Id.

158. King, supra note 145.

159. Dale Conder, Jr., FRCP Requirements: Expert Disclosures under Rule 26, FoR THE DEFENSE (July 2004); see Martin v. CSX Transp., Inc., 215 F.R.D. 554, 557 (S.D. Ind. 2003).

160. Martin, 215 F.R.D. at 557.

161. Id. (quoting Sircher v. City of Chicago, No. 97 C 6694, 1999 WL 569568, at *2 (N.D. Ill. July 28, 1999)). See also Butterfield v. Navistar Int'l Transp. Corp., No. 1:06-CV101-RLY-WTL, 2007 WL 2901693, at *2 (S.D. Ind. June 25, 2007) (holding that because the plaintiff had not indicated he was going to offer "any testimony from his physicianexperts beyond the appropriate scope of such testimony," no expert report was necessary).

162. McQuiston v. Helms, No. 1:06-cv-1668-LJM-DML, 2009 WL 554101, at *10 (S.D. Ind. Mar. 4, 2009) (quoting Martin v. CSX Trans., Inc., 215 F.R.D. 554, 557 (S.D. Ind. 2003)).

163. Id. 


\section{E. Lingering Problems}

Because of the lack of clear standards, problems have lingered and are likely to continue, notwithstanding the 2010 Rule 26 amendments. ${ }^{164}$ Even where courts have annunciated their own uniform standards, it remains difficult to determine whether a report is required because " $t]$ he dividing line may be between knowledge that [a] doctor has solely as a result of treating the patient, and analyses or insights the doctor develops at the behest of the patient's lawyer."165 Moreover, physician witnesses are often difficult to compartmentalize as lay witnesses or expert witnesses because they often toe the line between retained experts and treating physician witnesses. ${ }^{166}$ Additionally, preparing an expert witness report in accordance with Rule $26(\mathrm{~b})(2)(\mathrm{B})$ is time consuming even though counsel is allowed to assist the expert witness because the Rule requires that a doctor be "extremely thorough." 167

Many attorneys throughout the country are still struggling with these standards. ${ }^{168}$ Questions have been left open in the Seventh Circuit, including determining how far a treating physician may testify without producing an expert report. ${ }^{169}$ For example, could a treating physician "offer any opinions that are based solely on 'the facts made known to him [or her] during the course of the care and treatment,' even if the opinions are not essential to care and treatment ... a as long as the physician has not been 'specially retained' to develop that opinion?"170 In addition, what does "specially retained ... to provide expert testimony" mean? ${ }^{171}$ For example, if a patient's back was healthy before an accident but is fractured after the accident, and a doctor diagnoses the fracture and that he knows of no other medical causes that may be relevant to the treatment, would this be an opinion that transforms the doctor into an expert? ${ }^{172}$ Moreover, if a doctor diag-

164. See MASs. ConTINUING Legal EdUC., INC., supra note 50.

165. 8A WRIGHT ET AL., supra note 17.

166. See generally JAY E. GRENIG \& JeFFrey S. KinsLER, HANDBOOK OF FEDERAL Civil Discovery AND Disclosure $§ 1: 23$ (3d ed. 2011). See, e.g., Noffsinger v. Valspar Corp., No. 09 C 916, 2011 WL 9795, at *4 (N.D. Ill. Jan. 3, 2011) (finding that the doctor's records "show characteristics of both a treating physician and an expert hired to opine about causation").

167. 8A WRIGHT ET AL., supra note 17.

168. See James Beck \& Mark Herrman, Treating Physicians as Experts, DRUG \& DEVICE L. BLOG (Aug. 25, 2009, 8:00am), http://druganddevicelaw.blogspot.com/2009/08/ treating-physicians-as-experts.html. See generally King, supra note 145.

169. Cobble v. Wal-Mart Stores E., L.P., No. 1:10-CV-010, 2010 WL 1088513, at *2 (N.D. Ind. Mar. 19, 2010) ("[D]istrict courts in the Seventh Circuit have not adopted a uniform approach with respect to treating physicians and the expert report requirements of Rule 26(a)(2)(B).").

170. Joseph, supra note 30 , at 370 .

171. Id. at 371 .

172. This example was conceptualized through discussions with Indianapolis-area attorneys. 
noses lung cancer in a nonsmoker, does the diagnosis qualify as an expert opinion if the doctor concludes that it was caused by workplace exposure? ${ }^{173}$

This struggle to understand the implications of Rule 26 has also encouraged the tactical gamesmanship that is utilized by attorneys in an effort to avoid placing the label of expert on their treating physicians. ${ }^{174}$ Examples of tactics utilized by attorneys include "retaining two experts (one to testify and one as a consultant to do the work and develop the opinion), imposing contrived record-keeping practices, and wasting valuable deposition time exploring every communication between a lawyer and expert and every change to an expert report." 175 As a result, the amendments have had "a chilling effect on counsel's interactions with testifying experts," and attorneys have employed "various costly and counterproductive strategies to avoid making disclosures under the Rule.""176

This issue thus raises practical questions of how to avoid causing prejudice to both plaintiffs and defendants. For instance, if treating physicians are labeled fact witnesses or expert witnesses who do not need to produce expert reports, defendants may be prejudiced as a result because plaintiffs could purposefully circumvent full disclosure or use this quasi-loophole as an excuse to add an expert physician at the eleventh hour before a discovery deadline. ${ }^{177}$ The lack of a report requirement may even be exploited to sneak in an expert physician after a deadline. ${ }^{178}$ Alternatively, labeling a treating physician as an expert required to produce a report may prejudice plaintiffs whose treating physicians lack the time to complete an extensive expert report. $^{179}$

Moreover, treating physicians themselves may be reluctant to be des-

173. This example was conceptualized through discussions with Indianapolis-area attorneys.

174. Joseph, supra note 30 , at 372 (noting that the distinction between a true treating physician and the hired gun is "subject to manipulation (since a patient can always start treating with a new, lawyer-suggested doctor)").

175. Stephen G. Harvey \& Angelo A. Stio III, Amendments to Federal Rules of Civil Procedure to Take Effect on December 1, 2010, PEPPER HAMILTON LLP CLIENT ALERT, Dec.

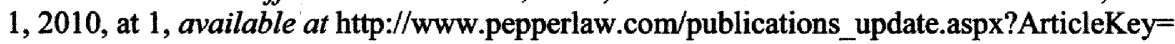
1953.

176. David Spears \& Christopher W. Dysard, Expert Testimony in Civil and Criminal Cases in the Federal Courts, in EXPERT WITNESS 2011, at 39 (PLI Litig. \& Admin. Practice, Course Handbook Ser. No. 31219, 2011).

177. See, e.g., Noffsinger v. Valspar Corp., No. 09 C 916, 2011 WL 9795, at *4-5 (N.D. Ill. Jan. 3, 2011) (where defendants claimed that patient's reputed treating physician was not actually a treating physician but was solely retained in anticipation, causing the "treatment" to be a façade).

178. See, e.g., id. (where defendants claimed that patient's reputed treating physician was not actually a treating physician but was solely retained in anticipation, and therefore the "treatment" was a façade).

179. Cohen \& Jacxsens, supra note 32 ("This will aid defense counsel both in developing strategy regarding their Rule 26 disclosures of treating physicians and in capitalizing on the opposing side's errors regarding disclosures of treating physicians."). 
ignated experts, and it is commonly difficult for attorneys to convince treating doctors to take the time to prepare for trial and to produce a detailed report before the treating physicians are even asked to testify. ${ }^{180}$ The report requirement may also negatively affect the health of patients because it takes time away from treatment and patient care. ${ }^{181}$ These resulting difficulties may affect the ability of patients to bring claims or defenses. ${ }^{182}$ Furthermore, the whole purpose behind Rule 26 seems to be defeated if true treating physicians are required to produce experts report because they were not retained in anticipation of litigation, when the 1993 Rule 26 Advisory Committee appeared to purposely exclude expert physicians from this extra burden. ${ }^{183}$

Finally, it is highly problematic that whether an expert report is required is dependent upon the district court in which the case was filed or the judge to whom it was assigned. ${ }^{184}$ Thus, courts may be encouraging forum or judge shopping, and, as such, justice may not be meted out equally amongst patients if a court later decides to prevent a treating physician from testifying due to the lack of an expert report.

\section{Changes to Rule 26(A) AND its Potential Ramifications}

The proposed amendments to Rule 26(a) that took effect in December 2010 may change the way courts view treating physicians. As a new addition to this section, Rule 26(a)(2)(C) provides that even an expert who is not required to produce an expert report under Rule 26(a)(2)(B) must still provide "a summary of the facts and opinions to which the witness is expected to testify."185 Hence, regardless of whether a treating physician needs to produce an expert report, there must be some cursory information provided by treating physicians to opposing parties.

This new obligation is "similar in substance to the pre-1993 version of Rule 26(b)(4)(A)," allowing for expert discovery through interrogatories. ${ }^{186}$

180. FED. R. Crv. P. 26 advisory committee's note (1993). See also Katherine A. Rocco, Rule 26(a)(2)(b) of the Federal Rules of Civil Procedure: In the Interest of Full Disclosure?, 76 FORDHAM L. REV. 2227, 2228-29 (2008).

181. Rocco, supra note 180. See also Watson v. United States, 485 F.3d 1100, 1107 (10th Cir. 2007).

182. FED. R. CIV. P. 26 advisory committee's note (1993).

183. Id. See also 8A WRIGHT ET AL., supra note 17 ("It seemed clear that the treating physician example was one reason why the Advisory Committee did not impose a report requirement on all testifying experts in 1993.").

184. Spears \& Dysard, supra note 176, at 40 ("[S]ome courts have required written reports even from exempted expert witnesses (for example, the plaintiff's treating physician)."). See, e.g., Sowell v. Burlington N. \& Santa Fe Ry. Co., No. 03 C 3923, 2004 WL 2812090, at *4 (N.D. Ill. Dec. 7, 2004).

185. FED. R. CIV. P. 26(a)(2)(C).

186. Gregory P. Joseph, 2010 Expert Witness Rule Amendments: The New Rules Will Eliminate Much of the Need for Maneuvers Once Used to Protect Communications with Experts, Prac. LiTIGATOR, Nov. 2010, at 55. 
However, the new obligation does not force a complete expert report from any expert witness who was previously exempted under the 1993 version of Rule 26(a)(2)(B). ${ }^{187}$ This added requirement may help "resolve[] a tension that has sometimes prompted courts to require reports under Rule 26(a)(2)(B) even from witnesses exempted from the report requirement," and a full report would still only be necessary from an expert described under Rule 26(a)(2)(B). ${ }^{188}$ The 2010 Advisory Committee Note concluded that this report is less burdensome than the export report requirement. ${ }^{189}$ However, the Committee cautioned courts to guard against making this requirement too onerous, urging them to "take care against requiring undue detail," and "[to] keep[] in mind that these witnesses have not been specially retained and may not be as responsive to counsel as those who have."190 Therefore, as long as these witnesses are identified under Rule 26(a)(2)(A) and provide the necessary disclosure under Rule 26(a)(2)(C), the witnesses may enjoy their hybrid status as a fact witness and an expert witness without being required to produce a Rule $26(\mathrm{a})(2)(\mathrm{B})$ report. $^{191}$

Accordingly, this new rule establishes a compromise, requiring a less burdensome expert report to be produced by a patient's treating physician, while concurrently giving the opposing party sufficient notice as to the content of the doctor's testimony. ${ }^{192}$ Some further mitigation for patients exists because a treating physician who testifies as both as an expert witness and a fact witness is not required to disclose the facts to which he or she is testifying as a fact witness. ${ }^{193}$ In other words, the "disclosure obligation does not include facts unrelated to the expert opinions the witness will present."194

Potential prejudices exist for both parties due to these 2010 Rule 26 amendments. ${ }^{195}$ There is now a written summary requirement for doctors who become ensnared in time-consuming litigation purely because of their profession, which requires treatment of patients. This added obligation may make doctors even more reluctant to testify. ${ }^{196}$ In addition, patients must

187. 8A WRIGHT ET AL., supra note 17.

188. FED. R. CIV. P. 26 advisory committee's notes (2010).

189. Id.

190. Id.

191. Id.

192. Jessie F. Beeber \& Marisa Sarig, Recent Amendments to Rule 26: How the New Rules Affect the Attorney-Expert Relationship, in EXPERT WITNESS 2011, at 129-30 (PLI Litig. \& Admin. Practice, Course Handbook Ser. No. 31219, 2011).

193. Id.

194. FED. R. CIv. P. 26 advisory committee's notes (2010).

195. Beeber \& Sarig, supra note 192, at 130.

196. See Proposed Amendment to FRCP 26-What Is It and How Will It Affect Litigation?, Nixon Peabody LlC Prod. Liab. Alert, Nov. 5, 2008, at 2, available at $\mathrm{http} / / / \mathrm{www}$.nixonpeabody.com/linked_media/publications/Products_Liability_Alert_11_05_ 2008.pdf ("A physician who may be considered a 'lay witness' under Rule $26(\mathrm{a})(2)(\mathrm{B})-$ testifying to a patient's diagnosis and treatment--may now be considered an 'expert' testifying to all opinions and the basis and reasoning for each. If a physician is considered an 'expert,' he or she may also have to provide a list of all publications written in the previous 10 
disclose the extent of the physician's expert testimony in this summary statement, and this physician will likely be restricted to testifying to only the information included in this statement. ${ }^{197}$ Consequently, patients suffering from new symptoms or receiving new diagnoses subsequent to the disclosure of the summary report may be prejudiced. Moreover, this process may be difficult for physicians because they will likely be asked to verify disclosures drafted by attorneys, whereas the physicians had previously drafted their own disclosures or verified their own records. ${ }^{198}$ There will also be an added expense for whoever formulates this summary report, thereby adding to the potential costs of litigation. ${ }^{199}$ The summary report requirement may also be more burdensome, particularly in cases where there are several treating physicians. ${ }^{200}$

However, the Rule 26 amendments simultaneously "may save both time and money associated with retaining experts and discovering their opinions." 201 Because these requirements are less burdensome than the current rule and may be drafted by attorneys, the time and money required to allow a patient's treating physician to testify will be significantly less. ${ }^{202}$ Further, as opposing parties will have access to the extent of a treating physician's testimony, less unfair surprises will occur, and "[s]uch summary reports may even eliminate the need for depositions."203

Party opponents stand to gain much information from this summary statement that they did not receive in the past when a party was determined to avoid producing an expert report. ${ }^{204}$ Defendants will now be able to obtain a general idea of the extent of a treating physician's expert testimony, but courts may be more reluctant to designate treating physicians as experts needing to produce a full-blown expert report. In these cases, defendants in

years and a list of cases in which he or she has testified at trial or deposition in the previous four years.").

197. FED. R. Crv. P. 26(a)(2)(C).

198. Id. Those covered under this rule will have to communicate to develop the written disclosure, but it does not need to be signed by the witness. Id.

199. Proposed Amendment to FRCP 26 - What is it and how will it Affect Litigation?, supra note 196.

200. See generally Michael A. Pollard et al., Proposed Amendments To Federal Rule of Civil Procedure 26 To Substantially Change Expert Witness Disclosure and Discovery Requirements, BAKER \& MCKENZIE CLIENT ALERT, July 2010, available at http:// www.bakermckenzie.com/files/Publication/dae4bb76-43bf-40de-9c38-0780543b4166 /Presentation/PublicationAttachment/06375892-844e-4307-b4d9-12c750a7d5d7/al_dr proposedamendmentsfederalrulecivilprocedure jul10.pdf.

201. Lance L. Shea et al., An Indispensible Force of Persuasion: Navigating Expert Discovery, FOR THE DEFENSE, Nov. 2010, at 14.

202. See generally id.

203. Proposed Amendment to FRCP 26-What is it and how will it Affect Litigation?, supra note 196.

204. See Proposed Amendment to FRCP 26 - What is it and how will it Affect Litigation?, supra note 196 ("The opposing party will be in a position to gather additional facts and witnesses as necessary, as they will be aware of potentially harmful or surprising opinions."). 
some jurisdictions may actually have even less access to information. ${ }^{205}$ Yet, because the new Rule 26(a)(2)(C) "draws no distinction between parties, in theory, defendants will have the same ability as plaintiffs to designate and describe the opinion testimony of plaintiffs' treating physicians."206

However, questions regarding this process still remain, and much will be left to the discretion of courts. ${ }^{207}$ For instance, it will likely be difficult to separate 'unrelated' facts from related facts which "could prompt the opponent to challenge, through motion practice, the sufficiency of presenting side's summary disclosures."208

Overall, it seems that while this new requirement may obviate some of the confusion that was created by the Rule 26 (a)(2)(B), the summary report requirement has potentially created new prejudices by different means. Ultimately, it appears that courts will again have to decipher an unclear standard in Rule 26(a)(2)(C) and create their own schematics. Similar to the splits of opinion that occurred after the adoption of Rule 26(a)(2)(B), divisions amongst courts and the use of various strategies will likely occur as a result of the new summary report requirement. Thus, by attempting to take steps forward through the addition of Rule $26(\mathrm{a})(2)(\mathrm{C})$, courts may actually be taking a step back by not drawing clearer standards.

\section{SUGGESTED FRAMEWORK}

\section{A. Taking into Account the Purposes of Treating Physicians' Testimony}

Because there have been conflicting opinions on the need to produce an expert report, now is the time to set the record straight on Rule 26(a)(2)(B). When considering which system to adopt, the Seventh Circuit should consider the purposes of the testimony of treating physicians: they "are not retained for purposes of trial," and thus "[t]heir testimony is based upon their personal knowledge of the treatment of the patient and not information acquired from outside sources for the purpose of giving an opinion in anticipation of trial.,209 Treating physicians are not chosen as experts by their patients, but instead "are witnesses testifying to the facts of their

205. Shea et al., supra note 201; Beeber \& Sarig, supra note 192, at 130 ("Although the amendment will imposes [sic] a new, albeit minor, obligation on non-retained experts, the rule might operate to relieve these experts in cases in which the court would otherwise be inclined to order a full report under Rule 26(a)(2)(B).").

206. Beeber \& Sarig, supra note 192, at 130.

207. See generally Pollard et al., supra note 200 (discussing the complexities created by this new requirement).

208. Id.

209. Christopher Dyer, Treating Physicians: Fact Witnesses or Retained Expert Witnesses in Disguise? Finding a Place for Treating Physician Opinions in the Iowa Discovery Rules, 48 DRAKE L. REV. 719, 729 (2000). 
examination, diagnosis, and treatment of the patient."210 In conducting his or her duties as a doctor, a treating physician will establish an opinion based on his or her examination of the patient and will often opine as to the patient's future prognosis. ${ }^{211}$ "These opinions are a necessary part of the treatment of the patient."212

Thus, "[a]fter all is said and done, most treating physicians are not retained by parties as expert witnesses," and just because treating physicians may be considered experts due to their scientific knowledge "does not change this reality."213 There is a difference between those experts who are retained in anticipation of litigation and treating physicians, which may justify treating the two differently. "Retained experts are tantamount to employees of the retaining party, whereas "[m]ost treating physicians . . . are related to the party only by virtue of the historical accident of having treated the party's injuries." 214 In addition, a treating physician's testimony is "often more relevant, material, and probative, than that of the retained expert who is not only paid for his testimony but often gleans it from a cold record."

Moreover, while there are potential prejudices for a party who is unaware of the extent of an expert's testimony, this is not often the case with a treating physician, and there are ways that patients can avoid causing any prejudice to opposing parties. "The Federal Rules of Civil Procedure approved by Congress do supply other mechanisms, besides formal reports, for extracting the views of an expert witness," and thus "sandbagging is not necessarily inevitable."216 These mechanisms include a party's Rule 26(a)(1)(A) disclosures of witnesses, Fed. R. Civ. P. 26(a)(1)(B)'s requirement of producing "all documents, electronically stored information, and tangible things that are in possession, custody, or control of the party and that the disclosing party may use to support its claims or defenses, unless solely for impeachment," depositions, individual document demands, and other discovery the court deems necessary and appropriate. ${ }^{217}$ Even if these protections are not enough, a party may be sanctioned under Rule 37 for failure to comply with any of the above, and "district courts are empowered to go above and beyond what the Rules prescribe" if need be. ${ }^{218}$

210. Id.

211. Id.

212. Id.

213. Id. at 738.

214. Id. at $738-39$.

215. Id. at 739 .

216. Watson v. United States, 485 F.3d 1100, 1108 (10th Cir. 2007).

217. Id.

218. Id. 


\section{B. Balancing Test Proposition}

The Seventh Circuit should enunciate a standard that would include balancing a number of factors against the interests of both parties. None of these factors are alone sufficient, and they all should be considered when deciding what type of witness the treating physician will be.

Treating physicians should not always have to be designated experts. There are situations in which treating physicians should remain fact witnesses. When a treating physician's testimony is limited to uncontroversial issues such as a patient's injuries, and both parties will not experience any surprises or prejudice as a result of his or her testimony, then the doctor should be considered a lay witness. For instance, there are times when a treating physician may have learned the underlying facts from personal observation or experience, ${ }^{219}$ or everything is available in the "cold record," and a treating physician is simply testifying as to the records that have already been produced to the other side. Situations such as these suggest that a treating physician should not suffer the burden of a summary report for such limited testimony.

- Courts should consider a number of factors to determine whether a treating physician is an expert who needs to produce a report versus a summary report. These should include:

- Did the physician ask to review medical records of another health care provider in order to develop his opinion testimony concerning the appropriateness of the care and treatment of the provider? ${ }^{220}$ Similarly, did the treating physician rely upon records, which were produced by his or her counsel or from any other person in order to establish his opinion? $?^{221}$

- Did the treating physician provide a great deal of analysis exclusively for trial, and was he compensated for this work? ?22 $^{22}$

- Did the client's attorney refer the patient to the physician for treatment?

- How was the physician compensated? Was his or her compensation determined by their time spent preparing to testify or testifying at trial? ${ }^{223}$

- How long has the physician treated the patient?

219. Robert E. LaRSEn, NAVigating the Federal TRial $\S 9: 46$ (2010 ed.).

220. Kirkham v. Société Air France, 236 F.R.D. 9, 12-13 (D.D.C. 2006).

221. Id.

222. John K. Rabiej, New Areas of Review by the Advisory Committee on Civil Rules, Including Rules 13, 15, 26(A)(2)(B), 48, and 62.1, and Broader Civil Procedure Projects, Including Time Computation, Summary Judgment, and Notice Pleading, in CIVIL PRACTICE AND LITIGATION TECHNiQues IN FEDERAL AND STATE COURTS (ALI-ABA Course of Study, 2007).

223. Kirkham, 236 F.R.D. at 12-13. 
- What is expected to be the depth of the physician's testimony?

- Was the injury considered by the treating physician known to the patient before the commencement of litigation?

- Was the opposing party aware of the extent and scope of the treating physician's treatment?

The Seventh Circuit should generally adhere to the approach that seems to have been embraced by a growing number of courts, including numerous district courts located within the Seventh Circuit. The primary consideration of a court should be whether the proposed testimony was part of the treating physician's personal knowledge of the facts. Then, the rest of the above factors should be considered on the balance of the circumstances to determine whether a full-blown expert report is necessary.

Suppose that an accident occurred where a plaintiff was injured and now sued the defendant for his injuries. If the treating physician were only to testify based upon his medical records and opinions, then courts should allow that treating physician to testify as to causation, prognosis, or permanency of injury or disability without producing an expert report. However, if a treating physician bases his testimony upon outside information provided by others, courts could reasonably categorize the physician as an expert witness. Accordingly, the treating physician would be required to complete an expert report. By looking to the length of treatment, the date when treatment began, the date the lawsuit was filed, and the date when the patient became aware of his condition, courts may get a sense of whether this doctor was retained solely for the purposes of litigation. Also, a patient that was referred to a physician by his attorney should also cause courts to raise an eyebrow because it is much more likely that doctor was retained as an expert witness for the purposes of the trial.

A court should also inquire into the opposing party's knowledge of the treating physician before determining an expert report is required. Accordingly, if an opposing party is fully aware of the extent of a treating physician's testimony, there is less of a need for the production of an expert report.

\section{When Treating Physicians Are Designated Experts Needing to Produce a Summary Report, What Should Be Included?}

Treating physicians will now likely be forced to produce a summary report even when they are only testifying to their own treatment and observations of plaintiff if current trends continue, and little guidance is offered as to what an acceptable summary report looks like under new Rule 
26(a)(2)(C). ${ }^{224}$ A mandate requiring summary reports from all treating physicians is especially concerning, considering that the guidelines for completing a report are inadequate, thus forcing the parties to guess at what the court will consider acceptable. One judge in the Southern District of Indiana has suggested that these analyses will be on a "witness-by-witness basis," 225 but other district courts in the Seventh Circuit have thus far not provided significant assessments on the substance of the summary reports by treating physicians.

The Seventh Circuit district courts should be mindful in crafting their own strategies under amended Rule 26 that while the new summary requirement eases the burden on those physicians who had previously been automatically required to complete an expert report, other treating physicians who were not in districts that required reports are experiencing a new burden. Hence, when determining what is required in this summary report, courts should err on the side of caution in favor of patients. Treating physicians are often vitally important to a patient's case and likely form the backbone of the evidence, and hence courts should be more lenient, particularly when opposing parties are aware of the extent of a treating physician's opinions and testimony.

Moreover, it is more reasonable to allow patients to submit a broader summary report as opposed to a specific report that may subsequently limit the extent of that physician's testimony. ${ }^{226}$ Opposing parties will have ac-

224. Valentine v. CSX Transp., Inc., No. 1:09-cv-01432-JMS-MJD, 2011 U.S. Dist. LEXIS 58813, at *10-11 (S.D. Ind. May 10, 2011).

225. Id. at *13 n. 1 .

226. See In re Yasmin \& Yaz (Drospirenone) Mktg., No. 3:09-md-02100-DRH-PMF, 2011 U.S. Dist. LEXIS 116575 , at *4-6 (S.D. Ill. Oct. 7, 2011) ("[T] party is [sic] required to provide are not tied to the witness's opinions. Instead, Rule C requires a summary of the 'facts and opinions to which the witness is expected to testify.' Clearly, pursuant to the plain language of Rule $C$ (and unlike the express requirement found in Rule B), the disclosing party is not required to provide the facts upon which the nonretained expert relied for his or her opinion. Rather, Rule $\mathrm{C}$ unambiguously states that the 'facts' and 'opinions' which must be provided are two distinct concepts. Therefore, ... to satisfy Fed. R. Civ. P. 26(a)(2)(C) a party . . need only disclose a summary of facts and a summary of opinions about which its otherwise non-reporting experts will be testifying. In that way, the requirements of this portion of Rule 26 are much less than 26(a)(2)(B). Even if one could suggest that the language in Rule $\mathrm{C}$ is ambiguous, the recorded proceedings of the Committee make it clear that the standard of less disclosure (rather than more) is to be required by district courts in Rule C disclosures."). C.f. Crabbs v. Wal-Mart Stores, Inc., No. 4:09-CV-00519-RAW, 2011 WL 499141 (S.D. Iowa Feb. 4, 2011) (limiting a physical therapist's testimony to "the subject matter, facts and opinions incorporated in his evaluation," which constituted his acceptable summary report). See also Carrillo v. Lowe's HIW, Inc., No. 10cv1603-MMA (CAB), 2011 WL 2580666, at *3 (S. D. Cal. June 29, 2011) (Plaintiff's treating physicians may ... testify as percipient witnesses regarding the treatment they rendered to plaintiff, including the plaintiff's presentment of symptoms, their diagnoses, the treatment they provided plaintiff, and the medical bills incurred for their treatment . . . . [They] are, however, precluded from offering opinions as to causation, and the plaintiff's future medical condition, the reasonableness of the medical expenses incurred, the expenses for future medical treatment, and any other opinions beyond the treatment they rendered to 
cess to the doctor's medical records, will be able to depose the treating physician, and thus will possess more than adequate notice of a treating physician's testimony. Consequently, opposing parties are unlikely to face unfair prejudice in the wake of a broader type of report so long as they have fair notice of a doctor's opinion testimony and time to prepare for it.

By employing a more liberal standard for the summary report requirement, the Seventh Circuit can even the playing field between patients and opposing parties. Treating physicians will be less burdened and less constricted, and opposing parties will still have sufficient notice which will help them avoid unfair prejudice.

\section{CONCLUSION}

The need for a clear standard has been apparent since the 1993 Rule 26 amendments, and with the addition of Rule $26(\mathrm{~b})(2)(\mathrm{C})$, the time is ripe to determine where treating physicians fall within the new schematic. Above all, the Seventh Circuit lacks uniformity in the way it determines the necessity of an expert designation, an expert report requirement, and a summary report requirement. Currently, where a treating physician belongs in Rule 26 may depend on the district or even the individual judge assigned to the case.

When considering whether to impose an expert report requirement, the foremost consideration of Seventh Circuit courts should be whether the doctor consulted records outside his or her scope of treatment in developing his or her testimony. The usual mark of a retained expert involves his or her use of other physicians' records or other outside information to develop his opinion. This standard is easier to interpret than the strategies of other courts. In addition, it will not be hard to utilize in Seventh Circuit courts because several courts have already implemented this standard. By additionally instituting the proposed balancing test, courts will be able to avoid requiring an expert report of those true treating physicians who consulted outside resources simply as a part of their treatment of the patient.

Determining the extent of the new summary report requirement will not be a simple process, but the Seventh Circuit should consider the burden that it imposes upon treating physicians and should adopt a broader approach to these reports unless unfair prejudice or surprise is likely to occur to an opposing party. If the history of the expert report requirement has taught us anything, it is the need for uniformity, and the Seventh Circuit should therefore adopt a single, clear standard, which leaves little room for manipulation by parties seeking to pass through quasi-loopholes.

The issue of treating physicians has been lingering long enough, and

plaintiff. Such testimony was subject to the disclosure requirements of Rule 26(a)(2)(C), and having failed to provide defendant with a summary of those opinions and the facts supporting those opinions, defendant would be unduly prejudiced to allow such testimony at trial or in any other proceeding."). 
the adoption of Rule 26(b)(2)(C) has forced the issue. It is time to find a proper place for treating physicians in the Seventh Circuit. 